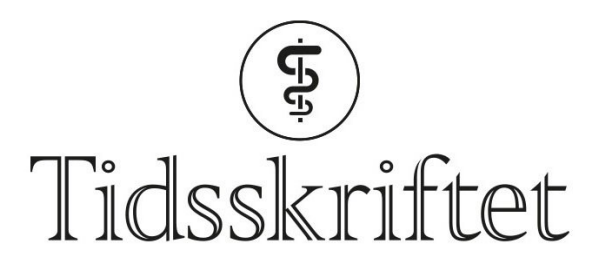

DEN NORSKE LEGEFORENING

\title{
L.C. Stene og medarbeidere svarer
}

KOMMENTAR

LARS CHRISTIAN STENE

E-post: lars.christian.stene@fhi.no

Lars Christian Stene er seniorforsker ved Avdeling for kroniske sykdommer og aldring, Folkehelseinstituttet.

PAZ LOPEZ-DORIGA RUIZ

BJØRN OLAV ÅSVOLD

VERA VIK BJARK $\varnothing$

ELIN PETTERSEN SøRGJERD

INGER NJØLSTAD

LAILA ARNESDATTER HOPSTOCK

KÅRE I. BIRKELAND

HANNE L. GULSETH

Ingen av forfatterne har oppgitt noen interessekonflikter.

Takk til Slåtsve og medarbeidere for interessante kommentarer og viktig supplerende informasjon (1) som illustrerer ett av hovedpoengene i vår kronikk (2): Det er ikke enkelt å fastslå prevalensen av diabetes i Norges befolkning. Verken våre registerdata eller data fra primærhelsetjenesten i et avgrenset område som Salten er perfekte for formålet, men kompletterer hverandre. Slåtsve og medarbeidere fant lavere prevalens i Salten i Nordland (3), enn vi gjorde for landet som helhet basert på registre (4).Vi har ingen umiddelbar forklaring på forskjellen, men har noen innspill som kanskje kan forklare noe.

Tallene fra Salten ble samlet i 2014, og må sammenlignes med de landsdekkende resultatene for Norge i 2014, ikke i 2020. Vårt estimat av type 2 diabetes i aldersgruppen 30-89 år i 2014 var $6 \%$, mot Slåtsve og medarbeideres 5,3\%. Et viktig spørsmål er om Salten skiller seg fra resten av landet. Vi har ikke svaret på dette uten tilgang på data på kommunenivå, men vi har fylkesvise data. Det var inntil 20 \% forskjell i prevalens mellom fylker i Norge i 2014, og vi har nå sammenlignet Nordland fylke mot resten av Norge i datasettet vi har brukt. Salten utgjør ca 1,5\% av Norges befolkning, og ca 1/3 av Nordlands befolkning. Vi fant at før 
korrigering for alder og fødeland, var prevalensen av diagnostisert diabetes drøyt $15 \%$ høyere i Nordland enn resten av landet. Etter korrigering for aldersfordeling og fødeland, var prevalensen i Nordland derimot ca $6 \%$ lavere enn resten av landet, primært fordi Nordland hadde en noe høyere andel av eldre. Det tilsvarer en prevalens på ca 5,6 \% i Nordland etter korreksjon for aldersfordeling. Det kan altså hende at prevalensen faktisk er noe lavere i Nordland, og kanskje også i Salten. Hvorvidt Salten skiller seg fra resten av Nordland er foreløpig ukjent. Dette kan sannsynligvis undersøkes i fremtidige studier. Som sagt er det god grunn til å tro at det er feilkilder i de fleste datakildene. For eksempel kan noen ha blitt registrert med diabeteskode i forbindelse med en utredning for diabetes som ikke nødvendigvis endte med en diagnose. Vi har forsøkt å ta høyde for dette ved å kreve minst to registreringer, men noen feil kan likevel ha sneket seg inn. Vi håper å kunne fortsette diskusjonen og hjelpe hverandre med å minimere feilkildene i fremtidige analyser.

\section{LITTERATUR:}

1. Slåtsve KB, Lappegård KT, Claudi T. Diabetes i Norge - ulike metoder gir ulike prevalensestimater. https://tidsskriftet.no/2020/12/kommentar/diabetes-i-norge-ulike-metoder-gir-ulike-prevalensestimate r Lest 12.12.2020.

2. Stene LC, Ruiz PL, Åsvold BO et al. Hvor mange har diabetes i Norge i 2020? Tidsskr Nor Legeforen 2020; 140. doi: 10.4045/tidsskr.20.0849. [PubMed][CrossRef]

3. Slåtsve KB, Claudi T, Lappegård KT et al. The total prevalence of diagnosed diabetes and the quality of diabetes care for the adult population in Salten, Norway. Scand J Public Health 2020 doi: 10.1177/1403494820951004. [PubMed][CrossRef]

4. Ruiz PLD, Stene LC, Bakken IJ et al. Decreasing incidence of pharmacologically and nonpharmacologically treated type 2 diabetes in Norway: a nationwide study. Diabetologia 2018; 61: 2310-8. [PubMed][CrossRef]

Publisert: 11. januar 2021. Tidsskr Nor Legeforen. DOI: 10.4045/tidsskr.20.1028

(C) Tidsskrift for Den norske legeforening 2020. Lastet ned fra tidsskriftet.no 